Отримано: 2 грудня 2019 року

Прорецензовано: 9 грудня 2019 року

Прийнято до друку: 11 грудня 2019 року

e-mail: olha.filonik@oa.edu.ua

svwinters@ucalgary.ca

DOI: $10.25264 / 2519-2558-2019-8(76)-18-20$
Filonik Olha, Winters Svitlana. Metaphors in brand names and advertising: pragmatic effect. Наукові записки Національного університету "Острозька академія»: серія "Філологія». Острог: Вид-во НаУОА, 2019. Вип. 8(76), грудень. С. 18-20.

\author{
Olha Filonik, \\ student, «Ostroh Academy» National University \\ Svitlana Winters, \\ PhD in Linguistics, University of Calgary
}

УДК: 659.1.013

\title{
METAPHORS IN BRAND NAMES AND ADVERTISING: PRAGMATIC EFFECT
}

The authors of the article extrapolate the existing knowledge regarding metaphors to the use of this figure of speech in some aspects of marketing (namely, product naming and advertising). The article contains the analysis of some examples of metaphors in brand and product names, as well as in advertisements. This article also presents a comprehensive overview of psycholinguistic literature on the effect exerted by metaphors on language users and, where the reasons are not obvious, proposes some explanations as to why certain effects may occur. The authors of the article argue that metaphors are a strong persuasive device. The following findings presented in psycholinguistic literature are referred to in order to support the authors' argument: 1) metaphors facilitate better understanding by creating multiple associations with the concept in question; 2) metaphors enhance the speaker's credibility and create a good impression of him or her: 3) metaphors lead to reduction in counter-argumentation; and 4) metaphors create a feeling of social closeness. The article provides an understanding of persuasive nature of metaphors and hence can serve as a guide to marketers who work on creating names for products, services and brands and who are involved in advertising of their products, services or brands.

Key words: metaphor, pragmatic effect, product name, advertising.

\author{
Філонік Ольга Юріївна, \\ студентка, Національний університет «Острозька академія» \\ Уінтерз Світлана Юріївна \\ кандидат філологічних наук, Університет Калгарі
}

\section{МЕТАФОРИ У НАЗВАХ ТОВАРІВ ТА В РЕКЛАМІ: ПРАГМАТИЧНИЙ ЕФЕКТ}

Автори статті екстраполюють наявні знання щзодо метафор на використання цієї фігури мови в деяких аспектах маркетингу (а саме у назвах товарів та в рекламі). У цій статті представлено вичерпний огляд психолінгвістичної літератури щчодо впливу метафори на носїв мови. Автори статті стверджують, щз метафори є потужним засобом впливу на покупия. Наступні висновки, представлені в психолінгвістичній літературі, наводяться для підтвердження даного аргументу: 1) метафори сприяють кращяому розумінню, створюючи численні асоціаџії з відповідною концепцією; 2) метафори підвищують довіру до людини, щзо їх використовує, і створюють гарне враження про нього чи неї; 3) метафори призводять до зменшення контраргументації; 4) метафори створюють відчуття сочіальної близькості. Дана стаття допомагає зрозуміти переконливу природу метафор, а отже може слугувати посібником для маркетологів, які працюють над створенням назв товарів та беруть участь у рекламі своєї продукиї.

Ключові слова: метафора, прагматичний ефект, назва продукту, реклама.

It has been frequently claimed in the literature that tropes-especially metaphors ${ }^{1}$-have a strong persuasive effect on people [14; 17-21]. For example, Read et al. [1990] found that presence of a metaphor in political passages led to significantly more positive ratings of the passages, as well as of the speakers delivering them. This finding supplements the findings presented by Reinsch [1971], which revealed that figurative language was more effective than literal language in changing people's attitudes $[18$, p. 144]. Namely, the comparison of the attitude towards the topic found in the pre-tests (i.e. prior to exposing the subjects to a persuasive political passage) with the attitude towards the same topic found in the post-tests (i.e. after the subjects were exposed to the persuasive political passages) demonstrated that attitudes tended to change when the political passage included tropes (metaphors and similes). Finally, studies of metaphors in advertising support the claim that metaphors have a persuasive effect [14; 18;21]. For example, subjects in Jeong [2008] gave higher evaluations to products and brands advertised with the use of visual and verbal metaphors, compared to the products and brands whose advertisements were not associated with any kind of metaphor. To be specific, after being exposed to advertisements with or without metaphors, subjects chose more favourable alternatives from the range "very likely to buy the product" to "very unlikely to buy the product" or "appealing brand" to "unappealing brand" when evaluating advertisements that involved metaphors [14, p. 66].

As a result of the perceived persuasiveness of metaphors, they are used increasingly more frequently in product naming and advertising. For example, a high number of automobiles contain a metaphor in their names (see (1) below). In these examples, some features of the animals are transferred onto the automobiles (e.g. speed, shape, grace, etc.)

(1) a. Jaguar

b. Volkswagen Beetle

c. Nissan Gazelle

d. Ford Mustang

${ }^{1}$ In this article, a metaphor is defined as a figure of speech that identifies something as some unrelated thing, thus highlighting the similarities between the two. 
Outside of the automobile industry, marketing specialists, employ names that create associations with some desirable qualities or features. For example, "Amazon" can potentially create associations with a fast stream and "Kayak" potentially makes customers think of a fun and smooth vacation.

(2) a. Amazon (technology company that focusses on e-commerce)

b. Kayak (travel agency and metasearch engine for vacation planning)

In other cases, even though the name of the brand or product does not contain a metaphor, metaphors are used in captions of advertisements (see (2) below). In the examples below, by using metaphors, marketing specialists reinforced, respectively, the following ideas: the drink will make you happy, the candy look like rainbow and your money will grow like a plant with Legal \& General Insurance.

(3) a. Coca-Cola. Open a little happiness.

b. Skittles. Taste the rainbow.

c. For vigorous growth, plant your money with us. Legal \& General Insurance.

The extensive use of metaphors in marketing makes the question regarding the persuasion mechanisms involved in employing metaphors fairly topical. This article will provide an overview of findings regarding persuasiveness of metaphors and attempt to explain why metaphors have a persuasive effect on the addressee. This will ultimately equip marketing specialists with a better understanding of metaphors and how they can be used effectively.

The relevant literature suggests that the following effects exerted by metaphors make them effective persuasion devices: enhancement of the communicator's credibility and the feeling of pleasure from grasping a metaphor [3], reduction in counterargumentation [12], activation of multiple semantic associations leading to better understanding, and creating a feeling of social closeness [20]. In what follows, these effects will be discussed in more detail.

Enhancement of communicator credibility due to use of metaphors was found by Bowers and Osborn [3]. In their experiment, subjects listened to political speeches and were asked to judge credibility (i.e. competence, trustworthiness and ingenuity) of the speakers delivering those speeches. One version of each speech ended in a metaphor while the other one ended with a literal conclusion. Bowers and Osborn [3, p. 151] found that the presence of a metaphoric conclusion had a significant influence on the judgments of the credibility of the speakers. It was revealed that communicators who use metaphors are judged more credible than the ones who use literal language. This effect may occur due to the feeling of pleasure accompanying the insight in the processing of metaphors and the assumption that only highly intelligent people are good at using metaphors in a clever and apt way. Bowers and Osborn [3, p. 147-148] argue that metaphors enhance communicator credibility by "stimulating mental processes in a manner which is intrinsically pleasurable", which "disposes us to be grateful to the speaker who has provided this pleasure and makes us receptive to his point of view" (such a view is also presented in Sopory and Dillard [20, p. 385]). Bowers and Osborn [3, p. 147-148] add that that apt and appropriate metaphor is taken by an audience as a sign of high mental ability, which is why one may expect the use of metaphor to increase the respect of the audience for the speaker and enhance faith in the speaker's competence.

Processing of a metaphor is said to involve reduction in counter-argumentation [12, p. 4], which may be attributed to the required enhanced elaboration, compared to processing of literal language [9, p. 32; 12, p. 4] (however, see Gibbs and Colston [10, p. 228] for an alternative view). The process of comprehending a metaphor generates a great number of associations that result in "an overload in the receiver's mental circuitry" [12, p. 4]. A high proportion of the cognitive resources of a language user are used up when encountering a metaphorical persuasive message and as a result fewer resources are left to "derogate or exclude the message content or the source" $[12$, p. $4 ; 20$, p. 386]. This leads to a greater agreement with what is advocated by the message.

As argued by Read et al., Sopory and Dillard, as well as Gibbs and Colston [17, p. 144-145; 20, p. 387; 10, p. 227], "metaphor may be more persuasive precisely because it often provides a more coherent structure for complex arguments, compared to literal language, which induces significantly more semantic associations..." [10, p. 227]. When these associations are consistent with the metaphor, the different arguments are connected more coherently via the many available semantic pathways. Consequently, addressees find it easier to relate the arguments to each other. This leads to richer understanding of the speaker's message. Enhanced comprehension, in turn, leads to an increase in persuasion [15]. The key idea here is that metaphor provides relevant semantic associations by which arguments of a message become linked, leading to higher persuasion [20, p. 387].

In addition to their persuasiveness, metaphors are known for their ability to establish a sense of intimacy between interlocutors [4, p. 9-10; 10, p. 224]. Figurative meaning can be inaccessible to all but those who share information about one another's knowledge, beliefs, intentions, and attitudes [4, p. 9]. Thus, it can be assumed that when communicating with a friend, one is more likely to use figurative language than when communicating with a mere acquaintance, which also leads to one perceiving a speech full of figurative language as that coming from a friend rather than a stranger. Linguistic characteristics of messages addressed to a friend, on the one hand, and to a generic 'other student', on the other hand, were studied by Fussell and Krauss [6]. The subjects of the experiment were asked to describe abstract figures so that their friend would choose the right figure from an array of figures based on this description. Later, the obtained descriptions were compared to the descriptions of the same figures produced in Fussell and Krauss [6] for 'another student'. Messages for a friend were more likely to be figurative (e.g. a warm in a tunnel) than literal (e.g. a curved line with a straight line inside), compared to messages intended for a generic 'other student' [6, p. 517 $]^{2}$. The finding that people who are close tend to use metaphors based on some shared knowledge is reiterated in Morelock [16]. The study of engravings on wedding bands revealed that in $25 \%$ of cases the couples chose metaphors, which seemed nonsensical to everyone else but were meaningful to them (for example, "Shine and gravity"), as the engravings on their wedding bands [16, p. 2]. Finally, it was found that those who use figurative language in their communication are perceived as being close, in contrast to those who do not [13]. Namely, Horton [13] conducted three experiments in which readers' sensitivity to interpersonal function of figurative language use was explored. Brief stories were created that described interactions between two ambiguously related characters. In the course

\footnotetext{
${ }^{2}$ However, the difference did not reach statistical significance, presumably due to a relatively low degree of intimacy involved in the friendship of the subjects involved in the experiment [6, p. 520].
} 
of those characters' conversations, one character always used either a metaphoric or literal referring expression to refer to some antecedent information from the story. Across all three experiments, readers consistently judged the story characters as knowing each other better and being closer when their interactions contained metaphoric references. To sum up, metaphors add some intimacy to communication.

Additionally, it has been found that the inclusion of metaphors can facilitate the memory of a message [10, p. 226]. For example, McQuarrie and Mick [15, p. 583-584) found that when their subjects were directed to process advertisements embedded in a magazine, they recalled those advertisements which contained verbal metaphors significantly better than those which did not. In addition, advertisements containing visual metaphors were recalled much better no matter whether the subjects were instructed to process the advertisements or whether they incidentally attended to them while looking through the magazine.

In sum, metaphors have been found to be a very helpful device in achieving certain pragmatic effects on language speakers. Namely, they can help one persuade the addressee, enhance credibility of the person using them, reduce counter-argumentation, create the impression of solidarity and belonging to the same social group, make a message more memorable and impress the addressee. This article provides an understanding of persuasive nature of metaphors and hence can serve as a guide to marketers who work on creating names for products, services and brands and who are involved in advertising of their products, services or brands.

\section{References}

1. Auble P., Franks J., Soraci S. Effort toward comprehension: Elaboration or aha!? Memory and Cognition. 1979. №7. P. $426-434$.

2. Berlyne D. E. Conflict, arousal, and curiosity. McGraw-Hill series in psychology. NY: McGraw-Hill Book Company, 1960. 366 p.

3. Bowers J.W., Osborn M.M. Attitudinal effects of selected types of concluding metaphors in persuasive speeches. Speech Monographs. 1966. №33. P. 147-155.

4. Cohen T. Metaphor and the cultivation of intimacy. Critical Inquiry. 1978. №5. P. 3-12.

5. Fussell S., Krauss R. The effects of intended audience on message production and comprehension: Reference in a common ground framework. Journal of Experimental and Social Psychology. 1989a. №25. P. 203-219.

6. Fussell S., Krauss R. Understanding friends and strangers: The effects of audience design on message comprehension. European Journal of Social Psychology. 1989b. №19. P. 509-525.

7. Colston H. Using figurative language. Cambridge: Cambridge University Press, 2015. 275 p.

8. Danek A.H., Fraps T., von Mueller A., Grothe B., Oellinger M. Aha! experiences leave a mark: facilitated recall of insight solutions. Psychological Research. 2013. №77. P. 659-669.

9. DeRosia E. Rediscovering theory: Integrating ancient hypotheses and modern empirical evidence of the audience-response effects of rhetorical figures. Go figure: New directions in advertising rhetoric. 2008. P. 23-50.

10. Gibbs R.W., Colston H. L. Interpreting figurative meaning. NY: Cambridge University Press, 2012. 390 p.

11. Gibbs R.W., Leggitt J., Turner E. Why figurative language is special in emotional communication. The verbal communication of emotions. 2002. P. 125-150.

12. Guthrie M. Effects of credibility, metaphor, and intensity on comprehension, credibility, and attitude change. Normal: Illinois State University unpublished master's thesis, 1972.

13. Horton W.S. Metaphor and readers' attributions of intimacy. Memory and Cognition. 2007. №35(1). P. 87-94.

14. Jeong S.H. Visual Metaphor in Advertising: Is the Persuasive Effect Attributable to Visual Argumentation or Metaphorical Rhetoric? Journal of Marketing Communications. 2008. №14(1). P. 59-73.

15. McQuarrie E., Mick D. Visual and verbal rhetorical figures under directed processing versus incidental exposure to advertising. Journal of Consumer Research. 2003. №29. P. 579-587.

16. Morelock C. Personal idiom use and affect regulation in romantic relationships. Lubbock: Texas Tech University unpublished PhD dissertation, 2005.

17. Read S., Cesa I., Jones D., Collins N. When is the federal budget like a baby? Metaphor in political rhetoric. Metaphor and Symbol. 1990. №5. P. 125-149.

18. Reinsch N. An investigation of the effects of the metaphor and simile in persuasive discourse. Speech Monographs. 1971. №29. P. $142-145$.

19. Sopory P. Metaphor and intra-attitudinal structural coherence. Communication Studies. 2008. №59. P. 164-181.

20. Sopory P., Dillard J. The persuasive effects of metaphor: A meta-analysis. Human Communication Research. 2002. №28. P. 382419.

21. Tom G., Eves A. The use of rhetorical devices in advertising. Journal of Advertising Research. 1999. №39. P. $39-43$. 